\title{
3歳未満児の自発性を育てる保育カリキュラムの開発 一エマージェント・カリキュラムを中心に一
}

Development of the child care and education curriculum to raise spontaneity of children under 3 :

With a focus on the emergent curriculum

\author{
阿部 和子 1 \\ 1大妻女子大学家政学部
}

Kazuko Abe ${ }^{1}$

${ }^{1}$ Department of Domestic Science, Otsuma Women's University

12 Sanban-cho, Chiyoda-ku, Tokyo, Japan 102-8357

キーワード : 保育カリキュラム, 3歳未満児の自発性, エマージェント・カリキュラム

Key words : Child care and education curriculum, Spontaneity of children under 3,

Emergent curriculum

\begin{abstract}
一抄録
本研究の目的は, エマージェント・カリキュラムの有効性を検討するものである. エマージェント・ カリキュラムは, 子どもの興味・関心 (自発性) から保育を組み立て展開することを特徵とするため,

「自立への欲求」が最も強く現れる 3 歳未満児の保育に適しているカリキュラムであると考えられる. 研究方法は, すでにエマージェント・カリキュラムを実践している保育園の保育者とともに, 過去の 指導案と実践の記録を持ちよって検討し, 指導案を作成するための視点を確認しながらエマージェン ト・カリキュラムについての有効性を確認するというものである.

得られた成果の一つは，3歳未満児の保育カリキュラム (年間計画, 月案, 週案) の分析を通して3 歳未満児の保育所における子どもの保育や子どもの育ちの姿の実態に即した計画をリアルタイムで 立案し実践できたことである．2点目は，エマージェント・カリキュラムの形式の開発の方向が明ら かになって来ていることである．3点目は，エマージェント・カリキュラムが「計画と実践」を往還 させるうえで有効であるということである，4点目は保育における日課（過ごし方）は，ただのスケ ジュールではなく「活動から活動への移行」を子どもがどのように経験するのかという点を重視する ことから、エマージェント・カリキュラムを支える重要な概念となることが示唆されたことである. 今後の課題として, エマージェント・カリキュラムの有効性を他者に伝えるための概念を検討するこ とである。
\end{abstract}

\section{1. 研究目的}

子ども・子育て支援新制度下では, 保育の質が 必須となっている。 ${ }^{[i]}$ 特に 3 歳未満児の保育の質 に関しては, 1998 年の乳児（3 歳未満児, 以下断 りがないかぎり，3歳未満をさす）が一般化され るまで，いわゆる必要悪という感を免れず，その 質に関して積極的に研究されてこなかった。 ${ }^{[i i] ~}$

以上の現状を踏まえて, 本研究の目的は人を育 てるものはその人自身の自発性にあるという考え 方に立ち ${ }^{[i i i],} 3$ 歳未満児の保育(生活)の在り方を, 自発性を中心にしたときにどのような保育 (生活)
が考えられるのかを，そのカリキュラムをもとに 検討することである.

\section{2. 研究の方法}

\section{(1) 研究会方式}

(1)研究会メンバー

$\mathrm{A}$ 県 B 市と C 市の社会福祉法人立保育園 4 園の 理事長・園長・主任クラスの保育者 8 名（内 1 名 大学教員を兼ねる）と筆者の 9 名である. 


\section{(2)研究会実施日時と検討内容}

\begin{tabular}{|c|c|c|}
\hline 回 & 日時 & 検討内容 \\
\hline 1 & $\begin{array}{l}\text { H. } 26.5 .17 \text { (土) } \\
\text { 13:30 17:30 }\end{array}$ & $\begin{array}{l}\text { 研究会趣旨の確認と今後の } \\
\text { スケジュール }\end{array}$ \\
\hline 2 & $\begin{array}{l}\text { H. 26.7.2（土） } \\
\text { 13:30 17:30 }\end{array}$ & $4,5,6$ 月の指導案の検討 \\
\hline 3 & $\begin{array}{l}\text { H. 26.9.6 (土) } \\
\text { 13:30 17:30 }\end{array}$ & $\begin{array}{l}\text { 6, 7, } 8 \text { 月の指導案の振り返 } \\
\text { り } 9 \text { 月の指導案の検討 }\end{array}$ \\
\hline 4 & $\begin{array}{l}\text { H. } 26.11 .29 \\
\text { (土) } \\
\text { 13:30 17:30 }\end{array}$ & $\begin{array}{l}9,10,11 \text { 月の指導案男振り } \\
\text { 返りと } 12,1,2 \text { 月の指導案の } \\
\text { 検討と学会発表原稿の作成 }\end{array}$ \\
\hline 5 & $\begin{array}{l}\text { H. 27.2.21 (土) } \\
\text { 13:30 17:30 }\end{array}$ & $\begin{array}{l}\text { 学会発表原稿の検討と資料 } \\
\text { の作成 }\end{array}$ \\
\hline
\end{tabular}

\section{（2）研究会で討議されたこと}

研究会メンバーの 4 園の月案と週案を持ち寄り, 実践記録をもとに, 計画と実践の往還の確認をし, 計画の様式や記録の仕方について検討した，検討 し修正された指導案の記録様式や保育記録の書き 方について修正を加え, 次の月の計画立案の留意 点を明らかにする。つまり，通常，各園で毎月行 う「計画一実践一記録（振り返り）－計画の修正 一実践...」という計画と実践の往還作業の一部を 研究会方式で, 4 園合同で行うというものである.

\section{3. 研究内容及び成果}

（1）なぜ，エマージェント・カリキュラムを検 討するのか（カリキュラムに対する考え方）

城戸 [iv] は，保育の計画は作業仮説であるとい う.つまり，保育は，保育の目標一その方向を目指 して行う保育の内容・方法などに対して計画を作 成することが常識的な考え方である.しかし, 実際 の現場を見回してみると計画を立案するがそれは 監査用 $[\mathrm{v}]$ であり，実際の保育は，「計画は計画， 実践は実践」という捉え方をしている現場は少な くないように思う。保育の質の低下が危惧される 現状において，作業仮説を持たない・あるいは習 慣で行う保育の展開は，子どもの発達を保障する 保育内容であるのかさえ検討ができないといえる.

本稿では，子どもの自発性の育ちを中軸に据え， 乳幼坚期の発達特性を踏まえた保育のカリキュラ ムはどうあればよいのかについて，最初に検討し た. 乳幼児期の発達特性を保育所保育指針 [vi] よ り引用すると以下の様になる。

(1)子どもは, 大人によって生命を守られ, 愛され, 信頼されることにより, 情緒が安定するとともに,
人への信頼感が育つ。そして，身近な環境（人， 自然，事物，出来事など）に興味や関心を持ち, 自発的に 働きかけるなど，次第に自我が芽生える. (2)子どもは，子どもを取り巻く環境に主体的に関 わることにより，心身の発達が促される.

(3)子どもは，大人との信頼関係を基にして，子ど も同士の関係を持つようになる。この相互の関わ りを通じて, 身体的な発達及び知的な発達ととも に, 情緒的, 社会的及び道徳的な発達が促される. (4)乳幼児期は，生理的，身体的な諸条件や生育環 境の違いにより，一人ひとりの心身の発達の個人 差が大きい.

(5)子どもは, 遊びを通して, 仲間との関係を育み, その中で個の成長も促される.

(6)乳幼児期は，生涯にわたる生きる力の基礎が培 われる時期であり，特に身体感覚を伴う多様な経 験が積み重なることにより，豊かな感性とともに 好奇心, 探究心や思考力が養われる.また，それ らがその後の生活や学びの基礎になる.

\section{(下線は筆者)}

ここに引用されたことから，保育所保育指針に 通底する子ども観は「大人によって守られる」こ とを土台にして「子どもを取り巻くものや人に興 味や関心を持ち，自発的に働きかける」ことを通 して，一人ひとりの心身の発達，自我，仲間との 関係，感性，好奇心，探求心，思考力が養われる という「主体的存在」を基底にしていることがわ かる。

主体的存在としての子どもの生活は，大人に支 えられながら, 身近な環境 (人, 自然, 事物, 出 来事など）に興味や関心を持ち，自発的に働きか けることが保障されることが必然であるとしてい る。 子どもの興味・関心を中心に計画を立てるの は, エマージャント・カリキュラムの特徴である.

“emergent”は「現れ出る」 ${ }^{[\mathrm{vii}]}$ という本義を持ち, 子どもの内側から外一現れ出る興味関心を捉える ことを意味する．また，「緊急の，不意の」という 意味もあるように，予測が難しくいつ現れるかも しれない子どもの活動の緊急性も表現している. エマージェント・カリキュラムは, 子どもの日常 生活の中でいつ・どこで, どのように現れるかも 予測が難しい緊急性のある子どもの興味・関心を 捉え，そこから保育を展開しようとするものであ る。このような視点は, 子どもの自発性を中軸に して主体性を育てる保育において本質的なもので 
あると考えられる。

\section{(2) 研究会で確認したこと（研究内容及び成果）} (1)様式: 記号の統一

研究会に参加している園の 3 か園は, すでにエ マージェント・カリキュラムを実践している (2001 年に研究会を立ち上げて以来実践をしている).

[viii] 筆者が参加した 2014 年には相当の実践を積ん できていたが，それを外部に説明する言葉を持ち 合わせていなかった。自らの保育実践に責任を持 つためには，他者に向けて説明責任を果たさなけ ればならない。 2014 年の第 1 回目の研究会に持参 した指導案は，一見するとウェブ式で形が整って いるように見えて，それぞれの園の書き方で書い ているので，そこに書かれている内容の検討に入 ると，いちいち項目間の関係や使われている記号 などを確認することが必要になった。そこで，他 者に説明する言葉の第一歩として，計画の中で使 われる記号を統一寸ることとした，以下がその例 である。

\section{<記号の例 >}

$\mathrm{A}$ 字の色 : 各クラスで計画された指導案は黒字,その指 導案を修正（主任の指導）は赤色,指導を受けて修正し た個所は青色,実践後に予想できなかった子ぞもの活 動や保育者の動きは緑色で著す。

B 囲み: 子どもは二重線の四角,ねらいは単線の長四角, ものは楕円,場所は二重線の楕円,行事は長楕円,予想し たが見られなかった活動などは点線の楕円で表す。

$\mathrm{C}$ 保育者の動き： $\triangle$ は環境構成,※は援助及び配慮事項 $\mathrm{D}$ 子どもの動き:四角は遊び,沁は日常の活動,○は季節 によって用意される活動など.

*エマージェント・カリキュラムは，この時点から計 画と記録が一体となった様式をめざしていることが理 解できる.

記号を統一することにより，話し合いがスムー ズに進んだ。そこでの話し合いを通して用いる記 号を修正していった。 また，エマージェント・カ リキュラムがウエブ式になっていくのは，時間と 空間のとらえ方が通常のカリキュラムと異なるか らである．子どもの主体性を重んじ，いつ現れる かわからない子どもの興味・関心から保育を組み 立てるとき，時間と空間を緩やかにしておくこと が最も重要になる。

\section{(2)カリキュラムの中の記録の重要性}

例えば，週案を作成する際の手続きは，目の前 にいる子どもの姿の理解一その姿から次の週の子 どもの保育のねらいを紡ぎ出すことが最初に行わ れる (1 年間の計画やその週の属する月の計画の 関係を意識しながら)。そして，次に，そのねらい に向けての内容を考え出す，その内容はどのよう な活動で経験できるのかという点から予想される 活動をできるだけ多く上げることになる，予想さ れる活動を多く考え出すということは，それだけ， 子どもの興味・関心に対応した環境づくりや準備 をすることが可能になる，さらに，それらの活動 の展開のための環境を構成し，その中での保育者 の援助や配慮事項を個別に考えておくことが，乳 児保育においては通常の週案作成の手続きとなる. エマージェント・カリキュラムにおいてもこの手 続きは同じである。 それでは，エマージェント・ カリキュラムと通常のそれとは，どこが異なるの か. 概していうと, 先にも少し触れたように, 時 間と空間に対する考え方の違いである.

ここにある保育園の 2 歳児クラスの通常に考え られる週案とそれをもとにして作成された週案と 日案の一部がある。 ${ }^{[i x]}$

\section{<週案>}

永らい: ○保育者に見守られたり，手助けを受けた りして，身の回りのことを自分でしようとする。 保育者友だちと一緒に体を動かして遊ぶことを楽し む. ○保育者を仲立ちとして，言葉をやり取りする 楽しさを味わう。

内容：、箸に興味を持ち，箸を使って食べようとす る. 手助けされながら簡単な衣服の着脱をする.

、走る, 跳ぶ, 登るなど全身を十分に動かして遊ぶ.

•見たことや感じたことを話したり「かして」「入れ て」などの言葉を使ったりして遊ぶ.

この週案のある一日の案として次のような日案が立 てられる。

\section{<日案>}

ねらい: ○スプーンと箸の両方を使って食べようと する．○保育者や友だちと一緒に体をいろいろに動 かす，全身を使って遊ぶことを楽しむ.

<内容 $>$ 手助けを受けながらパジャマのボタンを はめようとする。・好きな道具や遊びをみつけて遊 ぶ。・保育者や友だちと一緒に遊んだり，覚えた言 葉で話したりする.

この週案では，ねらい（○保育者に見守られた 
り，手助けを受けたりして，身の回りのことを自 分でしようとする。○保育者友だちと一緒に体を 動かして遊ぶことを楽しむ. ○保育者を仲立ちと して，言葉をやり取りする楽しさを味わう）に向 けての内容を、箬に興味を持ち，箬を使って食べ ようとする. 手助けされながら簡単な衣服の着 脱をする。 動かして遊ぶ。け見たことや感じたことを話した り「かして」「入れて」などの言葉を使ったりして 遊ぶことを上げている.

さらに，それを週の一日目の案（日案）として， 週のねらいに向けてより具体的な内容として，手 助けを受けながらパジャマのボタンをはめようと 寸る. 一好きな道具や遊びをみつけて遊ぶ. ・保 育者や友だちと一緒に遊んだり，覚えた言葉で話 したりするとしている，具体的な内容になればな るほど，ときどきの状況で現れる子どもの興味・ 関心に応答することが難しくなり，子どもの興味 関心を優先すると，計画は計画，実践は実践とい うことになりやすい。それは子どもの育ちを見通 して，計画的に保育することが難しくなる.

一方，計画に沿って保育をしようとすると，子 どもの興味・関心に添った活動への応答が難しく， 保育者主導の保育に陥りやすい。 子どもの興味・ 関心（今の子どもの主体の在りよう）を尊重しな
い保育では，子どもの主体性の発達は疎外される という課題を抱えることになる.

次の図 2 のカリキュラムは, 研究会のメンバー の園の 1 歳児クラスの B ちゃんの週案である（図 2 のウェブ状の部分). 週案は 1 歳児クラスのもの である、㸚らいは，図 1 の子どもを挟んで上下に 伸びる線でつながれた「身の回りのことを自分で できた喜びを感じる」「保育者と一緒にごっこ遊 びや見たて遊びをする中で友だちとのかかわり， 遊びを楽しむ」である。

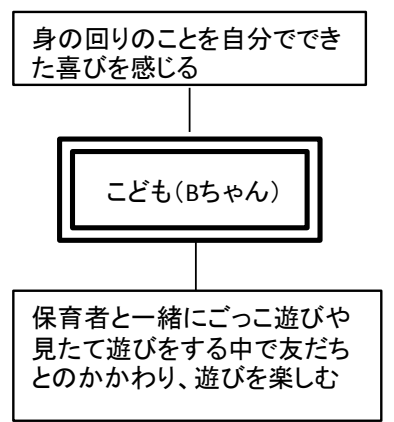

図 1 1歳児クラスの週日案 (11月 11 日から 20 日まで) のねらい

個人別日誌

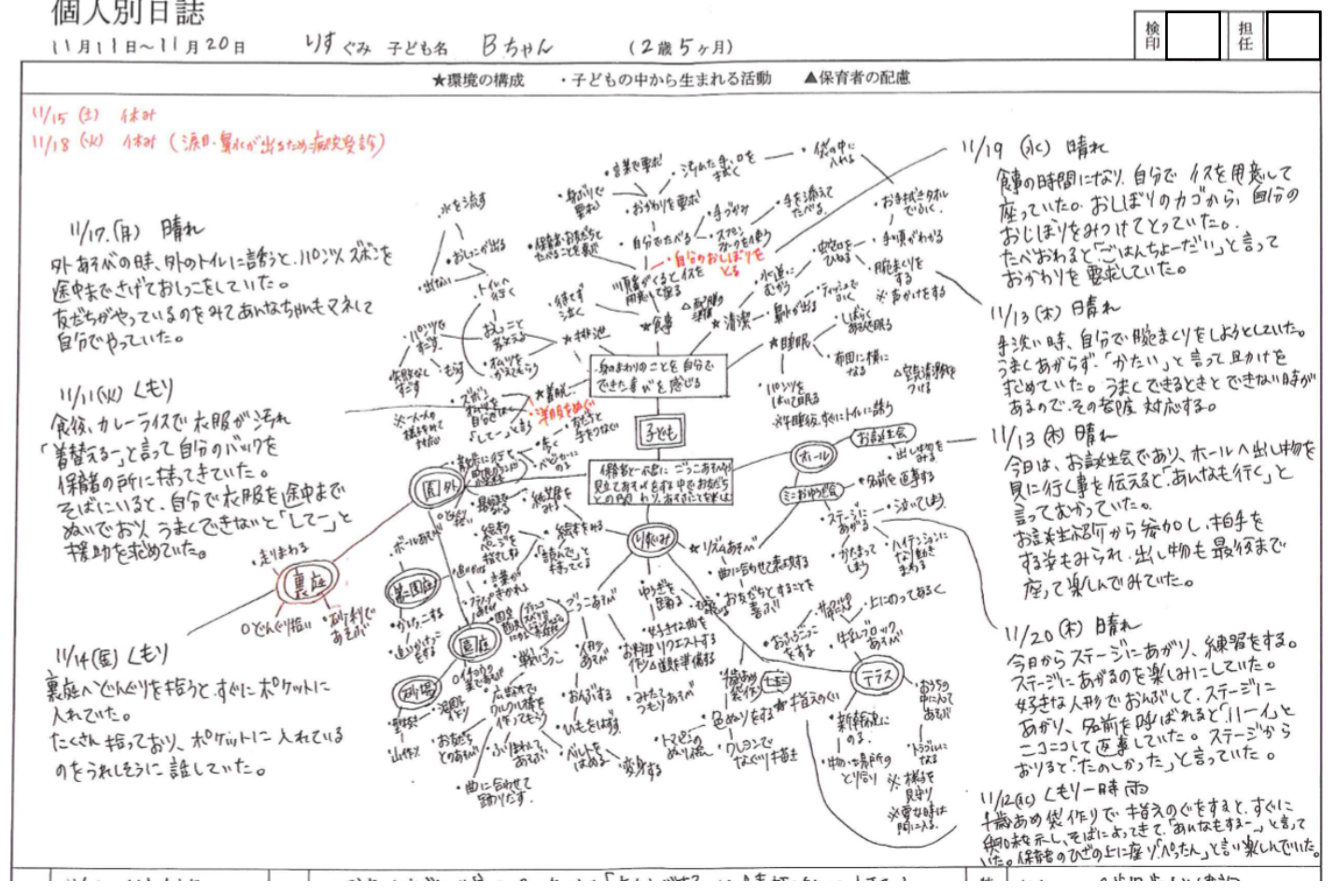

図 2 エマージェント・カリキュラムによる週案と実践記録（個別）のイメージ 
1 歳児クラスのこの時期のねらいは，どの子ど もの週案においても同じであり，週案のほぼ中央 に記入される。このねらいに向けての内容は，ク ラス全体の子どもたちの姿から導き出されるので, ある程度共通の内容が記入されることになる。こ こまでは，先にあげた一般的な指導案と同じであ る（様式は異なる）が，その内容がどのような活 動によって経験されるかは，様々な発達の過程に ある子どもたちの集団であるので，子どもによっ て異なることを考慮し，活動に幅を持たせた計画 になっている（図 2 の線でつなげられている内容 が展開されるであろう場所と合わせて予想される 限り書き込まれている)。 .また, 㸚らいに向けた活 動が，日々定められているわけではなく，1週間 の間に，あるいは 1 か月の間にその内容が様々な 活動を通して経験できるように時間的にも空間的 にも幅を持って計画されている.

週案に添って実践しながら，そこでの子どもの 姿を日々書き込んでいくため，週の途中でそれま でに計画されていなかった内容を付け足すことも ある。つまり，どんなに子どもの姿を理解して周 到に計画したとしても，保育の日常は様々な条件 の上に成り立っていることや，何よりも日々変化 する子どもの興味・関心を完全に読み切ることが 難しいことから計画の修正は当たり前に起こる. いつ現れるか予測しにくい子どもの興味・関心 (子 どもの自発性）から，保育を組み立てるのがエマ ージェント・カリキュラムである。

また，同じ 1 歳児クラスの子どもでも月齢が異 なり，その家庭的背景なども異なることなどから， 週のねらいは同じであってもそのねらいに向けた 内容は，子どもの興味・関心の現れが異なれば， その活動も異なるということも当然起こり得る. したがって，同じクラスで同じ㸚らいのもとに保 育されるが，そのねらいに向けた内容を経験する 活動は，子どもによって異なることがあり，それ を極力保障しようとするのがエマージェント・カ リキュラムの特徴である.

一人ひとりの子どもの興味・関心に沿って保育 を組み立てるエマージェント・カリキュラムは， 計画と実践の往還が必然的に行われる。この過程 は実践の結果を記録し，それをもとに振り返るこ とが可能になり，そのことが保育の質（子どもの 経験の質）を保障することにつながる.
(3)ねらいにそった内容がいつどのように現れたか

子どもの興味・関心がいつ現れるか予測がつき にくいことから，エマージェント・カリキュラム は，時間と空間を比較的緩やかに捉えていること は先に述べた通りである。図 2 の週案とその記録 から「身の回りのことを自分でできた喜びを感じ る」のねらいに向けた内容が様々な活動となって 現れていることをみていくと，表 1 の通りになる。 表 1 は，この指導案の 1 歳児クラスの 12 人の内, 5 人分をまとめたものである.縦軸に日課をとり, ねらい「身の回りのことを自分でできた喜びを感 じる」を経験している日にちを示したものである. また，表 2 はねらいに向けた経験をしている行動 を示したものである.

表 1 「身の回りのことを自分でできた喜びを感じる」 を経験している場面 (11月 11 日から 1 月 20 日まで)

\begin{tabular}{|l|l|l|l|l|l|}
\hline 日課 & A & B & C & D & E \\
\hline 登園時 & & & & & \\
\hline 遊び & $11 / 20$ & & $11 / 18$ & & \\
\hline おやつ·排泄 & $11 / 11$ & $11 / 13$ & $11 / 11$ & $11 / 11$ & $11 / 17$ \\
\hline 遊び & & & & & \\
\hline 昼食 & $11 / 10$ & $11 / 17$ & $11 / 12$ & $11 / 14$ & $11 / 11$ \\
& $11 / 14$ & $11 / 19$ & & & $11 / 19$ \\
\hline 午睡 & $11 / 18$ & & & & \\
\hline 排泄·おやつ & $11 / 17$ & & & $11 / 12$ & \\
\hline 遊び & & & & & \\
\hline 降園 & $11 / 13$ & & & & \\
\hline
\end{tabular}

注 : A（2 歳 7 か月 ), B（2 歳 5 か月 ), C（2 歳 2 か月）

D（2 歳 1 か月), E（2 歳 1 か月）である.

表 1 からは，保育園生活の様々な場面と時間に ねらいに向けた経験をしていることが理解できる. また，同じ 1 歳児クラスでもその月齢差で，現れ る回数が異なっていることが理解できる。たとえ ば，2 歳 7 か月の子どもA はより頻繁に「身の回 りのことを自分でできた喜びを感じている」傾向 にあることがわかる。一般的な発達過程からして も，3歳前後は，自己が獲得される時期とされて いる．子どもA は言葉で自己を主張することだけ ではなく（いわゆる反抗するだけではなく），その 主張（内面の在りよう）を行為することで自らの 
ものとする経験を多くしていると考えられ，それ

らの経験が自己の獲得を支えているということも

できる.

表 2 ねらいの具体的な経験内容（図 2 から関連部分の抜粋）

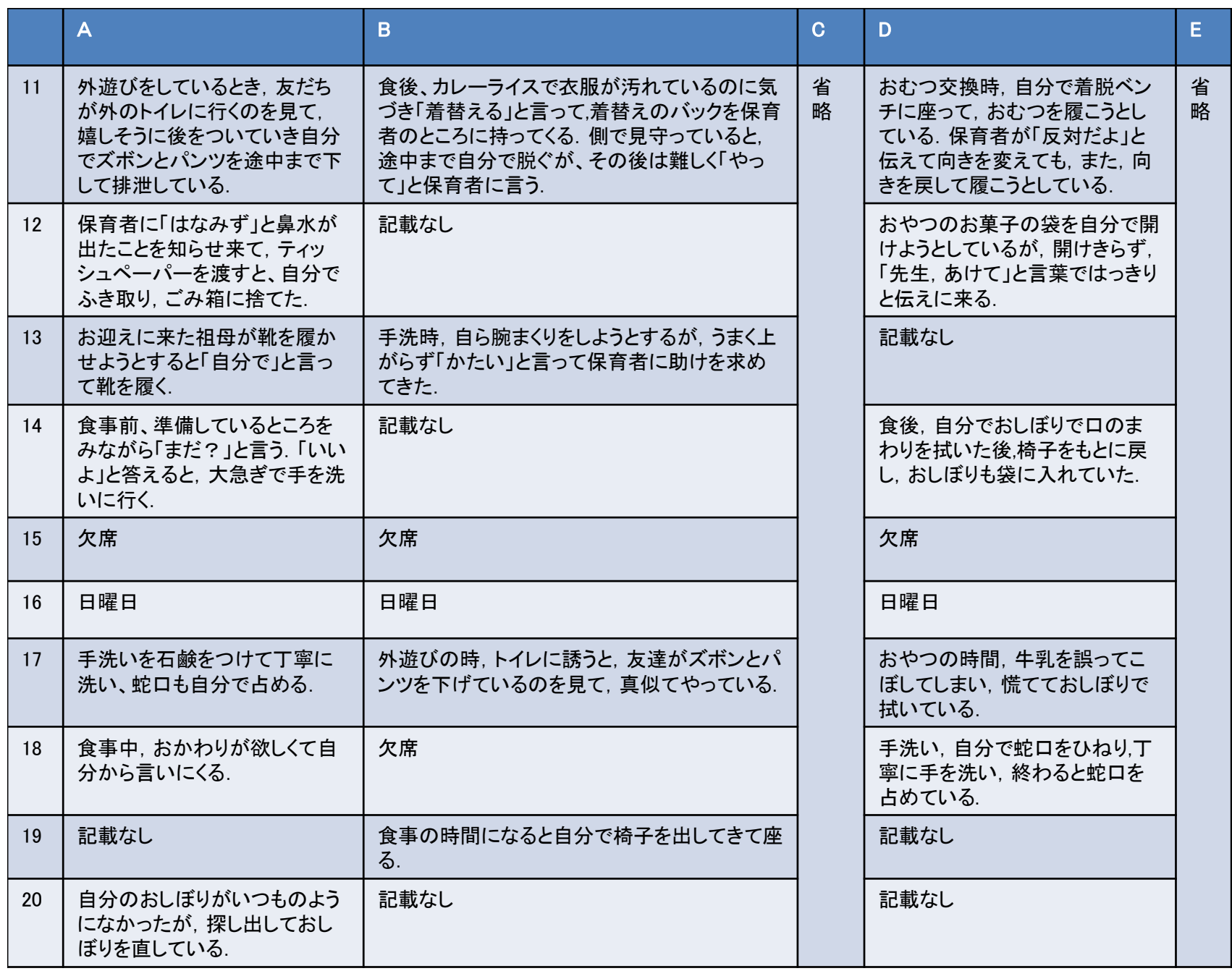

注 : 表中 $\mathrm{A} \sim \mathrm{E}$ は子ども

一方，2 歳になったばかりの子 D は，自己を主 張（表 2 の 11 日の記録）するが，他者の援助との 折り合いがうまくつけられずに，自己の主張に固 執しているところも見られるなど発達過程による 姿の現れの違いを見ることもできる.

以上の様に，計画に日々の実践（子どもの姿 : 活動や保育者の応答など）を書き込んでいくこと は，その週の終わりには，それがそのままその週 の保育の記録となる。つまり，計画に対する実践 の記録になり，その記録をもとにその週を振り返 り, 次の週の計画が立案されることになる，そこ
に，計画一実践一記録（振り返り）－計画が，日々 に往還され，更に，週で往還されるという，計画 と記録の一体化が実現する。ここでは計画は計画, 実践は実践，重要なのは実践であるというような 考えは払拭される.

\section{(4)日課}

保育園の一日は日課にそって流れている。この 0 歳児クラス日課は, 基本的に子ども一人ひとり の生理的なリズムが尊重される。したがって, ク ラスに 10 人のこどもがいたら，10 通りの日課が あるのが一般的である. 子どもを取り巻く大人は， 
この生理的なリズムを基本的に尊重しながら，昼 起きて夜寝るリズムになるように働きかけをして いく，我々の生活を成り立たせているリズムが， 基本的には夜寝て昼に活動することで成り立って いるので，無意識にでもそのような働きかけをし ている。 したがって，どのように子どもの主体性 を尊重しようとしても，生活の大枠を決める日課 は他から与えられるものである。

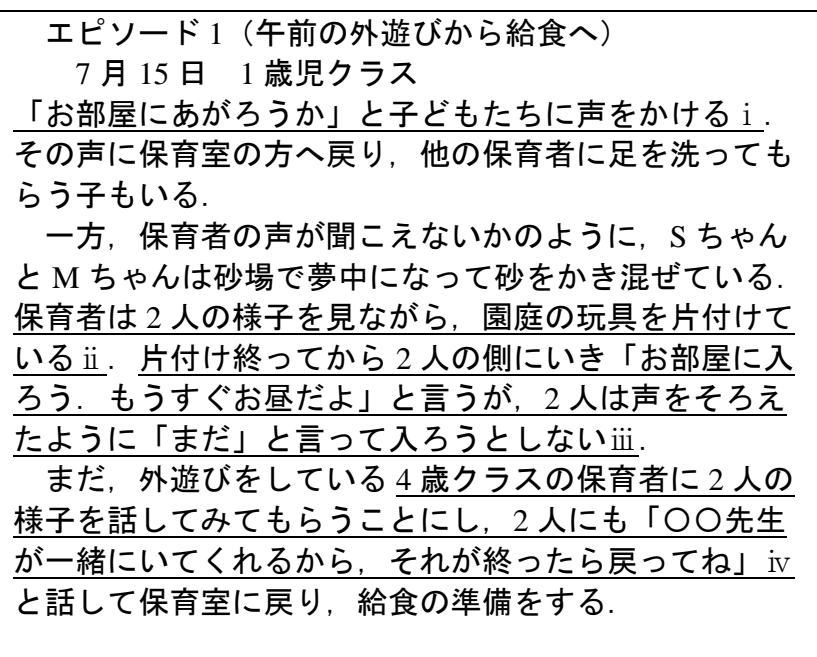

たとえば，1歳児クラスの日課は，多少の時間 の幅を持ちながら，集団の日課が成立する（表 1 の日課の項を参照). 子どもたちは, 与えられる日 課をどのように自らのものにしていくのか.つま り保育園の一日の時間を自らでコントロールして いくのか.

たとえば，遊びから給食へという活動から活動 への流れの中で，子どもは今の活動に区切りをつ けて次の活動へ向かうことになるが，時に，区切 りが付けられないことがある. 理由は様々である. エピソード 1 の 2 人の子どもは, 砂場の遊びから 給食への切り替えがなかなかできないでいる（こ この今から離れられない。遊びに夢中になってい る).

保育者は，子ども自ら今の活動に区切りをつけ て, 次の活動へ向かえるようにエピソードの下線 i , ii , iii， ivのように，急かすことなく対応し ている. 子どもたちは十分に満足して, あるいは, 保育者に子どもたちの気持ちが受け入れられたこ とに満足し，今の活動に区切りをつけて次の活動 へと向かう経験を重ねることになる.

以上のような子ども自らの「やりたい気持ち= 興味・関心」が受け入れられる経験を通して，生
活のリズム（活動から活動への切り替え）を自ら のものにしていくと考えることができる. 保育は, そこでの現象が整うことを目指すのではなく，子 どもの気持ちの満足（今の活動に自ら区切りをつ ける）一次の活動へという経験の積み重ねの上に 子どもの主体的な生活が成立してくる。これらの 経験は日課を例にとると，活動から活動への移行 の時間にゆとりを持つことが重要になる.

\section{4. まとめと今後の課題}

得られた成果の一つは，3歳未満児の保育カリ キュラム (年間計画, 月案, 週案) の分析を通し て 3 歳未満览の保育所における子どもの保育や子 どもの育ちの姿の実態に即した計画をリアルタイ ムで立案し実践できたことである．2点目は，エ マージェント・カリキュラムの形式の開発の方向 が明らかになって来ていることである. 3 点目は, エマージェント・カリキュラムが「計画と実践」 を往還させるうえで有効であるということである. 4 点目は保育における日課（過ごし方）は，ただ のスケジュールではなく「活動から活動への移行」 をどのように経験するのかというエマージェン

ト・カリキュラムを支える重要な概念であること が示唆されたことである. 今後の課題としては, エマージェント・カリキュラムの有効性を他者に 伝えるための概念を持つことである.

\section{注}

［i］子ども・子育て支援法（平成 24 年法律第 65 号), 就学前の子どもに関する教育, 保育等の 総合的な提供の推進に関する法律の一部を改正す る法律（平成 24 年法律第 66 号), 子ども・子育て 支援法及び就学前の子どもに関する教育，保育等 の総合的な提供の推進に関する法律の一部を改正 する法律の施行に伴う関係法律の整備等に関する 法律（平成 24 年法律第 67 号）をさして，子ども 子育て関連三法という。

[ ii ] たとえば，宍戸健夫「保育学の過去・現在・ 未来」保育学研究第 39 巻第 1 号, 2001, p.84 p.92, 渡邊保博「生活と生活習慣のとらえ方の変容が保 育計画に提起するもの」季刊保育問題研究, No.277, p. $19 \sim$ p.35

[iii］阿部和子, 前原寛「保育課程の研究一子ど も主体の保育の実践を求めて」萌文書林, 2009, p.7 $\sim$ p.19 
[iv ] 城戸幡太郎「保育の科学的研究」日本保育 学会編「保育の進歩」, フレーベル館, 1977, p.129 $[\mathrm{v}]$ 巟童福祉行政指導監查実施要綱览童福祉行 政指導監查実施要綱において,「指導監査は, 都道 府県知事が児童福祉行政の実施機関における览童 福祉施設の措置費等についての事務処理状況及び 児童扶養手当の支給事務処理状況並びに児童福祉 施設についての低基準等の実施状況が，関係法令 等に照らし適正に実施されているかどうかを個別 的に詳らかにし, 必要な助言・勧告又は是正の措 置を講ずることなどにより监童福祉行政の適正か つ円滑なる実施を確保しようとするものである」
と定められている.

［vi］全国社会福祉協議会編「保育所保育指針を 読む」全国社会福祉協議会 $\quad 2008$, p.16 p.17

[vii] 小西友七, 南出康世監修, ジーニアス大辞 典，大修館書店， 2014

[viii] 同上書 iii, p.65 p.75

[ix ］豊田和子・新井美穂子編著「保育カリキュ ラム論」建帛社，2013, p.55〜p.56

付記

本研究は大妻女子大学戦略的個人研究費

（S2603）の助成を受けたものである.

\section{Abstract}

The purpose of this study was to examine the usefulness of emergent curriculum. The emergent curriculum approach, characterized by its emphasis on constructing and evolving nursery child-care/education programs based on children's interests (spontaneity), is considered a suitable approach for children under three, the age group in which children's desire for independence is most strongly manifested. This study was conducted by discussing the usefulness of emergent curriculum with child-care providers from nursery schools that employ the emergent curriculum approach, with reference to their past activity plans and notes on implementation experiences, and to their perspectives on curriculum development.

This study produced the following four findings. First, analysis of the under-three curricula presented (annual, monthly, and weekly plans) revealed that the emergent curriculum approach enabled the child-care providers to develop and implement, in real time, curricula tailored to the actual child-care setting and the children's state of personal growth. Second, the direction being taken in development of the format of emergent curriculum has become clearer. Third, the emergent curriculum approach is a useful means of sustaining a feedback cycle between planning and implementation. Fourth, the results of this study suggest that a key concept for supporting emergent curricula would be to formulate daily activity plans not as mere schedules but as frameworks that put emphasis on how the children experience the transitions from one activity to another. A next step to follow this study would be to explore concepts for communicating to others the usefulness of the emergent curriculum approach.

(受付日：2016 年 3 月 23 日，受理日：2016 年 4 月 4 日）

\section{阿部 和子（あべ かずこ）}

現職 : 大妻女子大学家政学部児童学科教授

\section{日本女子大学大学院家政学研究科児童学専攻修了}

専門は保育学，現在は保育の実践の質に着目して，子どもの発達を保障する保育の計画について考察

し, 特に 3 歳未満児の保育について, 計画が実践と往還するための方策を研究している.

主な著書 : 保育課程の研究（萌文書林，2009）保育内容総論（全国社会福祉協議会，2011）

乳幼児期の「心の教育」を考える（フレーベル館 2001）

家庭支援論（萌文書林，2015） 